\title{
Does Social Trust Influence Charitable Giving for NGOs?
}

\author{
Halina Waniak-Michalak iD https://orcid.org/0000-0003-1857-4339 \\ Ph.D., Associate Professor, Accounting Department \\ Management Faculty, University in Lodz, Lodz, Poland \\ e-mail: halina.michalak@uni.lodz.pl
}

\author{
Ivana Perica (iD) https://orcid.org/0000-0001-8395-5096 \\ Senior lecturer, Department of Accounting and Auditing \\ Faculty of Economics, Business and Tourism, University of Split, Split, Croatia \\ e-mail: vana.perica@efst.hr
}

\section{Abstract}

The purpose of the paper is to find a link between the level of NGOs' revenues and the trust in non-governmental organisations (NGOs). We investigate if social trust, as measured by the Charities Aid Foundation, influences their charitable revenues. We analyse the revenues of NGOs in three countries: Poland, Croatia and the United Kingdom. We analyse the change in social trust in these countries and revenues in the years 2013-2017. The design and methodology approach includes a literature review and panel regression analysis. The main results of the panel regression analysis indicate that the amount of donations depends not only on the level of public trust but also on certain external and independent factors. We find that NGOs revenues vary from country to country due to different levels of economic development and wealth of countries. The results also show that apart from demographics, NGOs' revenues and the donations they receive are also influenced by the philanthropic goal, the number of years since it was established (the age of the organization) and the financing model. The research limitations include the selection of only a few countries for the analysis. This paper's originality and value lie in the fact that the problem of low social trust in NGOs is analysed by linking it with the NGOs' revenues.

Keywords: NGOs, civil trust, revenues, donations

JEL: M41, I31 


\section{Introduction}

Non-governmental organisations' (NGOs) incomes depend on public trust (Zasimova and Kolosnitsyna 2018). A decrease in public trust for NGOs is influenced by a lack of access to information on their performance, operational model, low experience, scandals (Charities Aid Foundation 2014; Mersianova, Jakobson, and Krasnopolskaya 2015), or the government's anti-NGO policy (Flikke 2016). The recent research from Waniak-Michalak et al. (2020), however, indicates that the development of accounting and other regulations of NGOs' activities do not affect the civil trust for NGOs.

Although low public confidence does not cause a decrease in philanthropy, it changes how the aid is distributed. Research shows that in many countries, people prefer giving money and other resources personally to those in need rather than through NGOs (Mersianova, Jakobson, and Krasnopolskaya 2015). Some researchers state that the decrease in social trust can influence NGOs' future charitable income and thus their ability to continue operations (Hou, Zhang, and King 2016; Zasimova and Kolosnitsyna 2018). The question if this is true is even more important in the face of recent accidents, epidemics, and the impending world economic crisis.

To answer the research question, we used a literature review, regression analysis, and non-parametrical tests. Three countries were selected for the research: Poland, with an average score among all post-communist countries in the World Giving Index ranking (Charities Aid Foundation 2018), Croatia - the first (the best) among all post-communist countries in the World Giving Index ranking (Charities Aid Foundation 2018), and the United Kingdom - one of the countries with the highest level of social trust.

Our paper is organized as follows. In the first section, we describe civil trust - its meaning, measurement, and connection with the development of NGOs. In the second section, we present research on the factors that influence the revenues of NGOs. In the third section, we describe the hypothesis development and methodology used. In the fourth section, we explain the panel regression analysis results that we conducted to determine if the social trust in particular countries influences NGOs' revenues. Finally, the conclusions are presented.

\section{Civil trust}

Donors can find it difficult to assess whether their goals and NGOs' achievements have been met because of information asymmetry. In most cases, owners (donors) who have specific expectations of the quality of NGOs' effects (goods, services, aid effects) may find it difficult to judge if they are satisfied. Even publicly available NGO reports may not solve the problem. Sargeant and Lee (2002) state that trust does not result from knowledge, but from faith; so trust depends not on the quality of information disclosed by NGOs but on the belief that someone controls them. 
Waniak-Michalak, Perica, and Leitoniene (2020) posit that other factors affect social trust, such as the lack of institutional mechanisms, the lack of an empathic society, and negative media coverage. Therefore, the level of trust will depend not so much on the effects of NGOs' current activities, but on indirect factors such as culture, other people's opinions, the economic and social situation, and general trust in private institutions. As public confidence in NGOs declines, the pressure on NGOs' accountability and control increases (Wallace 2004).

On the one hand, trust in any organisation can be undermined by embezzlement, low transparency, and corruption (da Cruz et al. 2015). On the other hand, civil trust may easily increase due to increased government oversight, the existence of watchdog agencies, and the introduction of ethical codes (Cordery and Baskerville 2011). Public trust in NGOs can also be built through international events, national government policies, disasters, and other crises, as well as EU policies (Kucheryavaya 2016). Social trust in NGOs can be determined by historical facts, culture, and the experience of citizens in establishing and supporting such organisations in the past. In countries that have been dependent on other countries for many years and in countries with regimes or communism, public trust for NGOs can be low. It is difficult to trust the unknown (Kucheryavaya 2016). Lee, Johnson, and Prakash (2011) posit that the media play an important role in creating trust in the NGO by providing information on their activities. Howard stated in 2003 that post-communist countries (like Poland and Croatia) have lower levels of development of the NGO sector than other countries.

Civil trust has three benefits for the charity sector: increased public funding, organisational stability, and ongoing independence (Cordery and Baskerville 2011). Scandals and accidents harm not only the organisation in which they occurred but the entire sector (Farwell, Shier, and Handy 2019). Without proper sector self-regulation and response to problems, social trust is falling for all NGOs, while affecting the revenues of the whole sector (Cordery and Baskerville 2011). However, as some cases show, social trust, even in the face of huge scandals, is restorable (Bryce 2007).

Researchers point to many factors that affect social trust, one of which is economic status (McDougle and Lam 2014). Grønbjerg's study (2009) shows that people with lower education levels and lower incomes have little trust in NGOs. Therefore, it should be assumed that the best opinion about NGOs will be held by donors, and the lowest by people who would be regarded as beneficiaries.

In 2014, Poland and Croatia saw an increase in public confidence, which can be linked to the natural disasters at that time. In the face of tragedy, people decide to donate, not to a specific organization, but to a specific purpose. In 2016 and 2017, a decrease in public trust in NGOs can be observed in Poland. The main reason for this was political changes, which also brought changes in citizens' world view. The media disclosure of facts indicating dishonesty of the management of some NGOs caused some citizens to turn against them. 


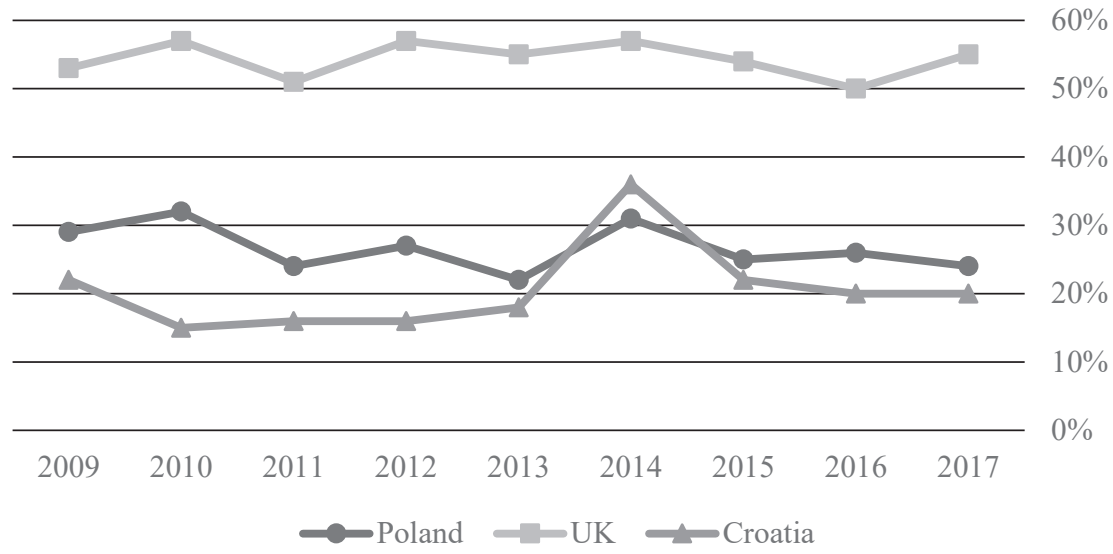

Figure 1. World giving index - global score, 2009-2017

Source: own elaboration based on data from the Charities Aid Foundation, https://www.cafonline.org/ (accessed: 1.01.2021).

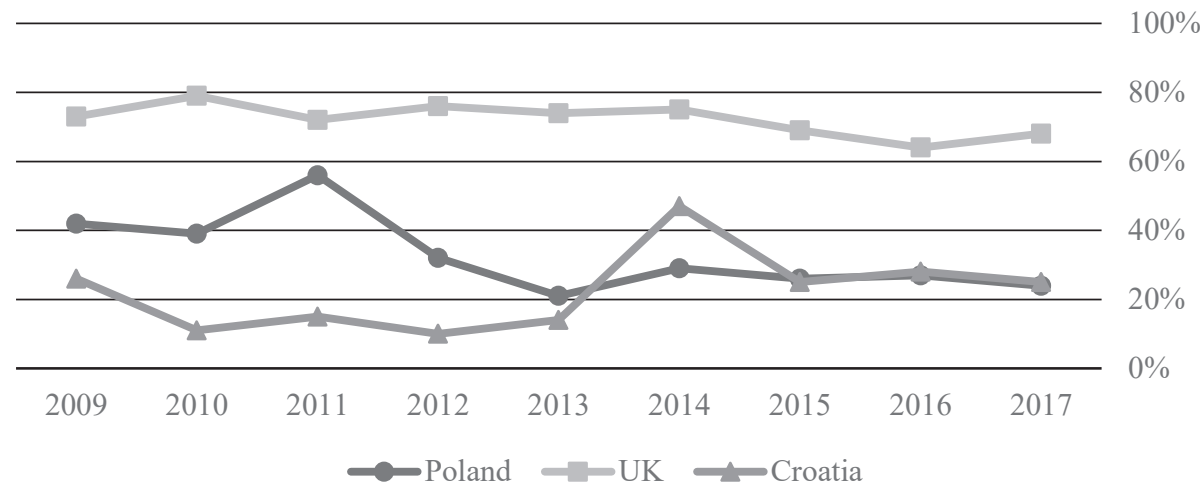

Figure 2. World giving index - for donating money, 2009-2017

Source: own elaboration based on data from the Charities Aid Foundation, https://www.cafonline.org/ (accessed: 1.01.2021).

Analysing Figures 1 and 2, it can be argued that general trust in NGOs does not always lead to an increase in philanthropic donations. One should remember that a donor is always financially better off not giving (Zagefka and Trevor 2015). Financial support for NGOs may be conditioned by economic or psychological factors (Mohammad et al. 2017), e.g. whether others also give, or whether the benefits for the donor are sufficient and visible (donors like to be publicly recognised for their generosity). List and Peysakhovich (2011) stated that giving aid is sensitive to economic factors such as GDP, S\&P ratio, and consumer spending. At the same time, they noted a negative correlation between the unemployment rate and individual giving. 


\section{NGO revenues and hypothesis development}

Some researchers state that the key source of NGOs' financing should be grants, not individual giving. NGOs that do not use public money to finance their activities struggle to survive (Burger and Owens 2014). Moreover, NGOs that have been awarded public grants in previous years are likely to receive it in subsequent years. Therefore, the likelihood of obtaining funding in these cases depends neither on efficiency nor public confidence, because grants are awarded based on habit rather than merit (Burger and Owens 2014, p. 1).

Lecy (2010) and Burger and Owens (2014) posit that larger and older organizations have a better chance of survival and higher income. The smallest organisations may be the least affected by changes in public trust, as they often benefit from the donations of a limited small group of donors (Wallace 2004). However, other research indicates that NGOs operating on a small scale, locally, may benefit from greater social trust than large organizations (Molenaers, Dewachter, and Dellepiane 2011). Prentice (2016) believes that NGOs' revenues are influenced by economic conditions such as GDP and regional revenues. Also, NGOs' revenues may be negatively or positively impacted by an economic crisis. During a crisis, organisations that rely heavily on government grants or individual donations may experience the greatest financial problems. On the other hand, crises stimulate volunteering and the diversification of funding sources for NGOs (Tzifakis, Petropoulos, and Huliaras 2017).

Some researchers believe that the individual characteristics of NGOs are not important for the amount of donations received. Focusing an organization on a specific purpose, allowing donors to choose the purpose for which their donations will be used, reduces the importance of other factors that influence the organization's income. However, this effect diminishes with the increase in the number of NGOs offering donors the possibility to manage their donations (Nunnenkamp and Öhler 2012). Also, NGOs' use of financing sources other than donations may result in a decrease in individual donations. In this case, donors may think that the organisation can manage without their support (Nunnenkamp and Öhler 2012).

The positive impact of public trust on the value of donations to NGOs has been identified in many publications (Çarkoğlu and Erdem Aytaç 2017). However, social trust is one of several factors influencing individual giving alongside demographic, economic, and cultural factors (Bekkers and Wiepking 2011). We also consider that research on factors that influence individual giving also indirectly concerns factors that influence social trust. Age, education, nationality, as well as the level of social trust, may justify the propensity to give. Trust in organizations may determine individual giving, but also supporting organizations may indicate high trust in them. Aytaç, Çarkoğlu, and Yıldırım (2017) have shown that trust in people does not determine the level of trust in organisations and vice versa. This conclusion is all the more surprising because NGOs operate as a result of the cooperation of many people, often neigh- 
bours, colleagues, and families. The level of trust in another person should influence trust in social organisations and thus, individual giving.

As many research papers state, people generally trust NGOs more than other organizations. However, the level of trust varies across countries and time (Rutley and Stephens 2017). Some authors claim that general trust in NGOs does not influence charitable giving (Hager and Hedberg 2016) and that the level of civil trust is characterized by low variability over time (O'Neill 2009).

Other researchers state that NGOs' revenues are formulated by NGOs' organizational and beneficiary characteristics (Aschari-Lincoln and Jäger 2015), such as their field and region of activity. We believe that philanthropic goals can have a significant impact on the organization's income. People most often support organizations that carry out activities considered by donors to be the most important. Different goals may be more important at different times, but certainly not every charity will enjoy the same public support. Similarly, the country of the activity or the territorial scope of the action (local, national, international) can have a significant impact on NGOs' revenues. As the scope of NGOs' activities increases, revenues may be higher.

The research presented above leads to the formulation of the research hypothesis.

H1. Social trust does not affect the organization's income; it is influenced by other external and independent factors.

We also formed detailed hypotheses:

H1.1 NGOs' revenues are determined by demographic and economic factors (Wiepking and Bekkers 2012; Prentice 2016);

H1.2 NGOs' revenues depend on the financing model of the organisation (Nunnenkamp and Öhler 2012; Burger and Owens 2014);

H1.3 NGOs' revenues depend on their age (Lecy 2010; Burger and Owens 2014); H1.4 NGOs revenues depend on their philanthropic goals.

We will concentrate on external and other than organizational choice factors that influence NGOs' revenues. We will not consider human resources management, project management, financial management, organizational management, or communication strategy issues as they are created and adjusted by the NGOs.

\section{Methodology}

The research was conducted on a sample of 167 NGOs from three countries: Poland, Croatia, and the UK. A total of 100 NGOs were selected for the sample from the NGO register in each country. Subsequently, we rejected NGOs that did not report for all years of operation in the period 2013-2017, those that were exempted from preparing financial statements due to low revenues, and those whose reports were incomplete, illegible, or did not use donations as a source of financing.

Following data collection, panel regression analysis was conducted for external factors that influence NGOs' revenues and World Giving Indices (WGI) for the coun- 
tries. We used the World Giving Index (global) and the World Giving Index (donating) as measures of social trust. Compared to WGI (donating), WGI (global) considers not only the willingness to make donations, but also the willingness to help others and spend time volunteering. The research cannot be conducted for the period 2018-2020 because the WGI is published with a one-year delay, and that the 2019 WGI ranking was not prepared by Charities Aid Foundation due to a change in the methodology of data collection in some countries and the need to determine the impact of this change on research results.

In the first stage, we used the pooled OLS as the estimator for panel data. Although this is unlikely to be adequate in most cases, it provides a baseline for comparison with more complex estimators. At the second stage of the analysis, we conducted an F-test to compare the pooled OLS against the principal alternatives, the fixed-effects and random-effects models. We chose the final estimator using the Hausman test to probe the consistency of the GLS estimates if OLS is not adequate.

The HDI (Human Development Index) was used as a proxy for the trust indicator (WGI), which, to a much greater extent than the GDP per capita indicator, measures the real standard of living of people worldwide and can thus be used as an economic and social measure. The following independent variables were used as representations of various dimensions of external and independent factors influencing revenues of NGOs:

1. HDI as a measure representing demographic and economic factors.

2. WGID - World Giving Index Global - as a measure of civil trust.

3. WGID - World Giving Index in donating - as a measure of civil trust.

4. SHARE - Share of donations in total revenues as an indicator of the organization's financing model.

5. AGE - number of years since the establishment of the organization.

6. GOAL - the main philanthropic goal/activity of the organization. We distinguished four areas of philanthropic aid: helping children (labelled 1); helping adults and generally sick people (labelled 2); helping animals and the environment (labelled 3); supporting sport and culture (labelled 4).

7. Country - as a control variable to differentiate between countries, 1 for Poland, 2 for Croatia, and 3 for the UK.

8. INTER - a dummy variable to recognise the international activities of the NGO that may influence revenues.

9. CORPF - a dummy variable to recognise if the NGO was set up by a corporation and receives grants from the founder every year.

Below in Table 1, we present descriptive statistics of the variables.

The descriptive statistics of continuous numerical variables indicate high variability of the values reported by the NGOs selected for the test sample. Donations from the surveyed NGOs constituted, on average, $50 \%$ of all income, although there were some NGOs that did not receive donations in particular years. This most often concerned young organisations whose income (mainly membership fees) in the first years of operation was 
very low. The age of organisations included in the research sample also varied. The sample included NGOs that had operated on the market for several decades and those that had been established between 2013 and 2017. Revenues and donations were transformed (standardized) by the amount of the average monthly salary in a given country in a given year. In this way, the nominal differences in NGOs' revenues between countries resulting from different income levels of the population were eliminated. Young organisations earned the lowest incomes. At the same time, a decrease in revenues and donations can be observed in subsequent years, despite the reported increase in trust in NGOs.

Table 1. Descriptive statistics of the variables

\begin{tabular}{|c|c|c|c|c|c|c|}
\hline \multicolumn{2}{|c|}{ Variable Year } & $\mathbf{N}$ & Mean & Std. Deviation & Minimum & Maximum \\
\hline \multirow[t]{6}{*}{ Share } & 2013 & 131 & 0.51 & 0.39 & 0.00 & 1.00 \\
\hline & 2014 & 158 & 0.48 & 0.39 & 0.00 & 1.00 \\
\hline & 2015 & 164 & 0.48 & 0.39 & 0.00 & 1.00 \\
\hline & 2016 & 166 & 0.50 & 0.39 & 0.00 & 1.00 \\
\hline & 2017 & 167 & 0.51 & 0.39 & 0.00 & 1.00 \\
\hline & Total & 786 & 0.50 & 0.39 & 0.00 & 1.00 \\
\hline \multirow[t]{6}{*}{ Age } & 2013 & 158 & 10.70 & 8.83 & 0.00 & 61.00 \\
\hline & 2014 & 164 & 11.27 & 8.94 & 0.00 & 62.00 \\
\hline & 2015 & 165 & 12.20 & 8.97 & 0.00 & 63.00 \\
\hline & 2016 & 167 & 13.04 & 9.03 & 0.00 & 64.00 \\
\hline & 2017 & 167 & 14.04 & 9.03 & 1.00 & 65.00 \\
\hline & Total & 821 & 12.27 & 9.02 & 0.00 & 65.00 \\
\hline \multirow[t]{6}{*}{ Revenues* } & 2013 & 158 & 668.30 & 3321.49 & 0.00 & 41078.80 \\
\hline & 2014 & 164 & 879.12 & 4177.16 & 0.00 & 48960.13 \\
\hline & 2015 & 165 & 856.14 & 3849.50 & 3.99 & 45738.27 \\
\hline & 2016 & 166 & 738.50 & 3555.94 & 4.15 & 45546.26 \\
\hline & 2017 & 167 & 849.66 & 3752.65 & 6.84 & 45516.33 \\
\hline & Total & 820 & 799.41 & 3736.73 & 0.00 & 48960.13 \\
\hline \multirow[t]{6}{*}{ Donations* } & 2013 & 158 & 396.00 & 3113.60 & 0.00 & 39129.38 \\
\hline & 2014 & 164 & 600.90 & 4022.64 & 0.00 & 46936.34 \\
\hline & 2015 & 165 & 590.83 & 3701.30 & 0.00 & 43605.89 \\
\hline & 2016 & 166 & 462.23 & 3376.40 & 0.00 & 43471.39 \\
\hline & 2017 & 167 & 579.69 & 3584.20 & 0.00 & 43251.06 \\
\hline & Total & 820 & 527.00 & 3567.83 & 0.00 & 46936.34 \\
\hline
\end{tabular}

* in amount of average annual salaries in the country in the year

Source: own elaboration of data from the NGOs financial and activity statements.

The results presented in Table 2 show that the lowest revenues are achieved by organisations that help animals and protect the environment. The Anova analysis showed that the differences between the averages in the different groups are significant, i.e. the organisation's purpose, country of operation, and international activity influence its total revenues and donations. The analysis also allowed us to categorize individual factors according to the means. 
Table 2. Means of categorical variables

\begin{tabular}{|l|l|c|c|c|c|}
\hline \multicolumn{2}{|c}{ Categorical variable } & \multicolumn{2}{c|}{ Donation } & \multicolumn{2}{c|}{ Revenue } \\
\cline { 2 - 6 } & N & Mean & N & Mean \\
\hline \multirow{5}{*}{ Country } & Poland & 287 & 919.86 & 287 & 1249.55 \\
\cline { 2 - 6 } & Croatia & 239 & 473.37 & 239 & 890.61 \\
\cline { 2 - 6 } & UK & 294 & 187.10 & 294 & 285.84 \\
\cline { 2 - 6 } & Total & 820 & 527.00 & 820 & 799.41 \\
\hline \multirow{5}{*}{ Goal } & Children & 243 & 1057.53 & 243 & 1371.07 \\
\cline { 2 - 6 } & Adults and sick people & 285 & 190.59 & 285 & 478.03 \\
\cline { 2 - 6 } & Animals and environment & 142 & 70.84 & 142 & 216.16 \\
\cline { 2 - 6 } & Sport and culture & 150 & 738.57 & 150 & 1036.08 \\
\cline { 2 - 6 } & Total & 820 & 527,00 & 820 & 799,41 \\
\hline \multirow{5}{*}{$\begin{array}{l}\text { Internationalivity } \\
\text { activy }\end{array}$} & No & 711 & 480.17 & 711 & 745.63 \\
\cline { 2 - 6 } & Yes & 109 & 832.76 & 109 & 1149.89 \\
\cline { 2 - 6 } & Total & 820 & 527.03 & 825 & 799.37 \\
\hline
\end{tabular}

Source: own elaboration of data from the NGOs' financial and activity statements.

\section{Results and discussion}

Conducting the F-test, we compared the pooled OLS against the principal alternatives, the fixed-effects and random-effects models. We chose the final estimator using the Hausman test to probe the consistency of the GLS estimates if OLS is not adequate. It turned out that all four MNK panel models were not correct, but models with established effects were more appropriate. The Wald test demonstrated that time effects were not significant and thus not included in the models.

Table 3. Panel regression analysis (models with fixed effects)

\begin{tabular}{|l|c|c|c|c|}
\hline \multicolumn{1}{|c|}{ Variables } & $\begin{array}{c}\text { logdonation } \\
\text { (Model 1) }\end{array}$ & $\begin{array}{c}\text { logrevenue } \\
\text { (Model 2) }\end{array}$ & $\begin{array}{c}\text { logdonation } \\
\text { (Model 3) }\end{array}$ & $\begin{array}{c}\text { logrevenue } \\
\text { (Model 4) }\end{array}$ \\
\hline const & $38.35^{*}(20.25)$ & $36.23^{* * *}(6.19)$ & $19.31(12.71)$ & $29.45^{* * *}(7.82)$ \\
\hline SHARE & $2.58^{* * *}(0.66)$ & $-0.06(0.04)$ & $2.59^{* * *}(0.67)$ & $-0.06(0.04)$ \\
\hline HDI & $-44.09^{*}(25.85)$ & $-42.25^{* * *}(7.90)$ & $-19.49(15.62)$ & $-32.93^{* * *}(9.70)$ \\
\hline AGE & $0.03^{* * *}(0.01)$ & $0.01^{* * *}(0.001)$ & $0.03^{* * *}(0.01)$ & $0.01^{* * *}(0.002)$ \\
\hline WGIG & $6.95(6.63)$ & $8.21^{* * *}(2.05)$ & - & - \\
\hline WGID & - & - & $0.19(2.68)$ & $3.97^{* *}(1.62)$ \\
\hline R2 (adjusted) & 0.45 & 0.16 & 0.45 & 0.15 \\
\hline
\end{tabular}

Robust standard errors in parentheses

*** $\mathrm{p}<0.01 .{ }^{* *} \mathrm{p}<0.05 .{ }^{*} \mathrm{p}<0.1$

Source: own elaboration of data from NGOs' financial statements, data from the Charities Aid

Foundation, https://www.cafonline.org/ (accessed 1.01.2020); data on Subnational Human

Development Index (4.0), https://globaldatalab.org/shdi/shdi/POL/?interpolation=0\&extrapolation=0\&n earest_real=0 (accessed: 1.01.2020). 
In the results presented in Table 3, four variables (INTER, COUNTRY, CORPF and GOAL) were included in the fixed effects, which indicated that they influence the NGOs' revenues and donations. It also indicates that there are significant differences in the NGOs' revenues from each country as measured by the amount of average salaries. The differences are also visible in nominal values, which is due to the countries' different levels of economic development and wealth. The variable that determines international activities has been shown to be significant, so NGOs that operate internationally have better chances of attracting donors from other countries and collect donations for their activity as they include more people all over the world.

The regression analysis (Table 2) has established that public trust, as measured by the World Giving Index, does not affect the amount of donations received by NGOs. Only for revenues was the social trust measure with the willingness to donate significant. We cannot interpret this anomaly, i.e., why for donations the measure is not significant, but for total revenue it is. The sign of WGID is positive in both models; however, only for total revenues is it significant. We conclude that it may result from the wrong presentation of financial data in the statements that we used. In some statements, the position "donations" or "voluntary income" could be undervalued, and some types of donations were included in other positions of the income statement. Also, in the survey where Charities Aid Foundation respondents were asked about the donations they made, they could think about things that they purchased from foundations, playing a lottery, or other activities. The revenues from these kinds of events are presented in other positions of the income statement, as revenue from sales or other charitable activities.

At the same time, another measure proved to be important for donation levels - HDI, an indicator that measures not only the level of socio-economic development but also the level of happiness. This would confirm previous observations of increased generosity of society in crisis and disasters. Moreover, as other research indicates, poorer people give a substantially greater proportion of what wealth they have (Zagefka and Trevor 2015).

The impact of HDI on NGO revenues can also be explained by Bekkers and Wepking's theory (2011). They identified eight potential mechanisms as being important for motivating donations: "awareness of need," "solicitation," "costs and benefits," "altruism," "reputation," "psychological benefits," "values," and "efficacy." In difficult times (i.e. a crisis), the consequences of not helping others can be worse than the consequences of helping (or the costs). It is not about choosing between benefit and cost, but the cost of helping and the cost of not helping. One of the three components of HDI is the life expectancy index - the lower the life expectancy at birth, the lower the HDI. Some studies (according to terror management theory) demonstrate that an awareness of one's mortality can increase donations (Greenberg and Arndt 2012).

However, the most significant aspect for the value of donations and total revenue is the age of NGOs, which can be a sign of experience and reputation. Young NGOs spend more time establishing their organization's reputation and building donor base, Age is also correlated with size, so they can afford professional fundraising staff mem- 
bers. Trussel and Parsons (2007) used NGO age as the measure of their reputation. They also posited that new organizations need time to establish themselves with donors and achieve name recognition. Our findings are in line with the result of a study by Lee (2017), who found that smaller revenue in organizations in Africa is significantly associated with a shorter age of organizations. Berret and Holliday (2018) also state that older organizations have greater resources.

Donations also depend on the share of donations in total revenue. Our research indicates that the amount of donations received by NGOs depends on their business model. The more significant the source of funding, the more can be expected. Organizations that have decided to run a commercial activity or to use public funding will put less emphasis on obtaining donations.

\section{Conclusions}

This article is part of a broad scientific discussion on the importance of public trust in the activities of non-governmental organisations. In the era of growing competition of NGOs for financial resources, it is extremely important to know which factors influence the amount of resources they obtain. The main aim of this study was to state whether and how the level of public trust and external, independent factors influence the donations received by NGOs. To answer this question, research was conducted on a sample of NGOs from Poland, Croatia and the United Kingdom, between 20142017, to examine the impact of demographic and economic factors, social trust, age of the organisation, the purpose of the activity, and the international activities of the NGOs on the donation income. The article found evidence of certain external and independent factors that influence the donations NGOs receive.

The main results of the panel regression analysis indicate that the amount of donations depends not only on the level of public trust, but also on certain external and independent factors. We conclude that public trust is not a critical factor for the volume of donations. This study provides further evidence of external and independent factors and links them to the volume of donations in relation to previous studies.

This study gives an insight into the external and independent factors underlying charitable activities, showing how they positively influence the donations to NGOs. We find that NGOs' revenues vary from country to country, due to different levels of economic development and wealth. The results also show that apart from the demographic area, the amount of revenues and the amount of donations to NGOs are also influenced by the NGO's philanthropic goal, age and financing model.

Among the surveyed NGOs, the lowest income and donations were achieved by young organisations and organisations that help animals and protect the environment. We also found that when NGOs operate internationally, they are more likely to attract donors from other countries and collect donations for their activities by engaging more people from around the world. These results also show that a higher HDI, 
an indicator that measures not only the level of socio-economic development but also the level of happiness, is important for donations. This confirms previous findings of the literature on the increased generosity of society during crises and disasters.

Our research indicates that the greatest importance for the value of donations and total revenues is the NGOs' age. We believe that age can be a sign of experience and reputation, which can positively influence the amount of donations. This study also shows that the amount of donations received by NGOs depends on their business model. This suggests that as donations become a more important source of funding, higher levels of donations can be expected. Organisations that have decided to perform commercial activities or use public funds will put less emphasis on acquiring donations.

Finally, our findings show that NGOs income is determined by demographic and economic factors and that it depends on their financing model, age and philanthropic goals. These results are part of the current debate about the problem of public trust and charitable donations.

Our study has several limitations. Our survey is based on an analysis of revenue and public trust in selected countries; hence, the results cannot be generalised. Moreover, the study aimed to verify the hypothesis concerning the impact of selected factors on NGOs' revenues. It is necessary to conduct research to determine why general public trust does not affect the amount of donations and what elements influence the creation of public trust.

The results of this study extend existing findings and explanations by identifying factors that have an impact on the amount of revenues from donations. Finally, these results may help practitioners manage non-profit organizations to make them more effective in collecting donations.

\section{References}

Aschari-Lincoln, J., Jäger, U.P. (2015), Analysis of Determinants of Revenue Sources for International NGOs: Influence of Beneficiaries and Organizational Characteristics, "Nonprofit and Voluntary Sector Quarterly", 45 (3), pp. 612-629, https://doi.org/10 .1177/0899764015595721

Aytaç, S.E., Çarkoğlu, A., Yıldırım, K. (2017), Taking Sides: Determinants of Support for a Presidential System in Turkey, "South European Society and Politics", 22 (1), pp. 1-20, https://doi.org/10.1080/13608746.2017.1280879

Bekkers, R.H.F.P., Wiepking, P. (2011), A literature review of empirical studies of philanthropy: Eight mechanisms that drive charitable giving, "Nonprofit and Voluntary Sector Quarterly", 40, pp. 924-973, https://doi.org/10.1177/0899764010380927

Berret, J.L., Holliday, B.S. (2018), The Effect of Revenue Diversification on Output Creation in Nonprofit Organizations: A Resource Dependence Perspective, "Voluntas", 29, pp. 1190-1201, https://doi.org/10.1007/s11266-018-00049-5 
Bryce, H.J. (2007), The public's trust in nonprofit organizations: The role of relationship marketing and management, "California Management Review", 49 (4), pp. 112-131, https://doi.org/10.2307/41166408

Burger, R., Owens, T. (2014), Receive Grants or Perish? The Survival Prospects of African Nongovernmental Organizations, "Credit”, 11 (7), pp. 1284-1298.

Charities Aid Foundation (2014), CAF World Giving Index: A global view of giving trends, https://www.cafonline.org/about-us/publications/2014-publications/caf-w orld-giving-index-2014 (accessed: 1.01.2021).

Charities Aid Foundation (2018), CAF World Giving Index: A global view of giving trends, https://www.cafonline.org/about-us/publications/2018-publications/caf-w orld-giving-index-2018 (accessed: 1.01.2021).

Cordery, C.J., Baskerville, R.F. (2011), Charity Transgressions, Trust and Accountability, "International Journal of Voluntary and Nonprofit Organizations", 22, pp. 197-213, https://doi.org/10.1007/s11266-010-9132-x

Cruz, N.F. da, Tavares, A., Marques, R.C., Jorge, S., Sousa, L. de (2015), Measuring local government transparency, "Public Management Review”, 18 (6), pp. 866-893, https://doi.org/10.1080/14719037.2015.1051572

Çarkoğlu, A., Erdem Aytaç, S. (2017), Determinants of Formal Giving in Turkey, "Journal of Muslim Philanthropy \& Civil Society”, 1 (1), https://doi.org/10.18060/21409

Farwell M.M., Shier M.L., Handy F., 2019, Explaining Trust in Canadian Charities: The Influence of Public. Perceptions of Accountability, Transparency, Familiarity and Institutional Trust, "Voluntas", 29 (4), pp. 768-782, https://doi.org/10.1007/s11266 -018-00046-8

Flikke, G. (2016), Resurgent authoritarianism: the case of Russia's new NGO legislation, "Post-Soviet Affairs", 32 (2), pp. 103-131, https://www.tandfonline.com/doi/abs/10 $.1080 / 1060586$ X.2015.1034981

Greenberg, J., Arndt, J. (2012), Terror management theory, [in:] P.A.M. Van Lange, A.W. Kruglanski, E.T. Higgins (eds.), Handbook of theories of social psychology, Sage, 1, pp. 398-415, https://psycnet.apa.org/doi/10.4135/9781446249215.n20

Grønbjerg, K.A. (2009), Are nonprofits trustworthy? Bloomington: Indiana Nonprofit Sector: Scope and Community Dimensions, https://nonprofit.indiana.edu/doc/pub lications/trustsurvey2008.pdf (accessed: 12.04.2021).

Habibpour M.M., Peiffer, M., Pepermans, R., Jegers, M. (2017), How giving affects giving: a long-term analysis of donations, "Applied Economics", 50 (21), pp. 2402-2413, https://doi.org/10.1080/00036846.2017.1397853

Hager, M.A., Hedberg, E.C. (2016), Institutional trust, sector confidence, and charitable giving, "Journal of Nonprofit \& Public Sector Marketing”, 28 (2), pp. 164-184, https://doi.org/10.1080/10495142.2015.1011508

Hou, J., Zhang, C., King, R.A. (2016), Understanding the Dynamics of the Individual Donor's Trust Damage in the Philanthropic Sector, "Voluntas", 28 (2), pp. 648-671, https://doi.org/10.1007/s11266-016-9681-8

Kucheryavaya, E.V. (2016), The Role of NGOs in the Development of Societies and Overcoming the Consequences of Crises: Case Studies of Poland and Russia, "Polish Political Science Yearbook”, 45, pp. 167-177, https://doi.org/10.15804/ppsy2016013 
Lecy, J. (2010), Sector Density, Donor Policy, and Organizational Demise: A Population Ecology of International Nonprofits, Social Science Maxwell School of Syracuse University, https://citeseerx.ist.psu.edu/viewdoc/download?doi=10.1.1.567.8827\&rep=r ep1\&type=pdf (accessed: 1.01.2021).

Lee, T., Johnson, E., Prakash, A. (2011), Media Independence and Trust in NGOs: The Case of Post-Communist Countries, "Nonprofit and Voluntary Sector Quarterly", 41 (1), pp. 8-35, https://doi.org/10.1177/0899764010384444

Lee, W. (2017), Sustainability of Nonprofit Human Service Organizations in a Neighborhood Context, "Nonprofit Management \& Leadership”, 28 (1), pp. 11-24, https:// doi.org/10.1002/nml.21264

List, J.A., Peysakhovich, Y. (2011), Charitable Donations are More Responsive to Stock Market Booms than Busts, "Economics Letters", 110, pp. 166-169, https://doi.org/10 .1016/j.econlet.2010.10.016

McDougle, L., Lam, M. (2014), Individual and community-level determinants of public attitudes toward nonprofit organizations, "Nonprofit and Voluntary Sector Quarterly”, 43 (4), pp. 672-692, https://doi.org/10.1177/0899764013479830

Mersianova, I., Jakobson, L., Krasnopolskaya, I. (2015), Giving in Russia: The Difficult Shaping of the New Nonprofit Regime, [in:] P. Wiepking, F. Handy (eds.), The Palgrave Handbook of Global Philanthropy, Palgrave Macmillan, London, pp. 249-266, https://doi.org/10.1057/9781137341532_15

Molenaers, N., Dewachter, S., Dellepiane, S. (2011), Moving into The New Aid Approach, Dilemmas for NGOs: The Belgian Case, "Public Administration and Development", 31, pp. 188-204, https://doi.org/10.1002/pad.600

NCVO, Charity law and regulation, https://www.ncvo.org.uk/policy-and-research/ch arity-law-and-regulation (accessed: 27.10.2020).

Nunnenkamp, P., Öhler, H. (2012), How to Attract Donations: The Case of US NGOs in International Development, "The Journal of Development Studies", 48 (10), pp. 1522-1535, https://doi.org/10.1080/00220388.2012.685720

O’Neill, M. (2009), Public confidence in charitable nonprofits, "Nonprofit and Voluntary Sector Quarterly", 38 (2), pp. 237-269, https://doi.org/10.1177/0899764008326895

Prentice, C.R. (2016), Understanding nonprofit financial health: Exploring the effects of organizational and environmental variables, "Nonprofit and Voluntary Sector Quarterly”, 45 (5), pp. 888-909, https://doi.org/10.1177\%2F0899764015601243

Rutley, R., Stephens, I. (2017), Public Trust and Confidence in Australian Charities, https:/www.acnc.gov.au/tools/reports/public-trust-and-confidence-australian-ch arities-report-2017 (accessed: 5.04.2020).

Sargeant, A., Lee, S. (2002), Individual and contextual antecedents of donor trust in the voluntary sector, "Journal of Marketing Management", 18 (7-8), pp. 779-802, https:// doi.org/10.1362/0267257022780679

Subnational Human Development Index (4.0), https://globaldatalab.org/shdi/shdi/PO $\mathrm{L} /$ ? interpolation $=0$ \&extrapolation $=0$ \&nearest_real $=0$ (accessed: 1.01 .2020$)$.

Trussel, J.M., Parsons, L.M. (2007), Financial Reporting Factors Affecting Donations to Charitable Organizations, "Advances in Accounting Volume", 23, pp. 263-285, https://doi.org/10.1016/S0882-6110(07)23010-X 
Tzifakis, N., Petropoulos, S., Huliaras, A. (2017), The Impact of Economic Crises on NGOs: The Case of Greece, "Voluntas", 28, pp. 2176-2199, https://dx.doi.org/10 .1007/s11266-017-9851-3

Wallace, T. (2004), NGO Dilemmas: Trojan Horses Forglobal Neoliberalism? „Socialist Register", 40, pp. 202-219.

Waniak-Michalak, H., Perica, I., Leitoniene, S. (2020), From NGOs" Accountability to Social Trust: The Evidence from CEE Countries, "Zeszyty Teoretyczne Rachunkowości”, 169, pp. 173-192, http://dx.doi.org/10.5604/01.3001.0014.4347

Waniak-Michalak, H., Perica, I., Leitoniene, S., Chojnacka, E. (2020), The Institutional Settings of the Recovery of the NGO Sector in Post-Communist Countries, "Comparative Economic Research. Central and Eastern Europe”, 23 (3), pp. 133-154, https:// doi.org/10.18778/1508-2008.23.24

Wiepking, P., Bekkers, R. (2012), Who Gives? A Literature Review of Predictors of Charitable Giving, http://www.wiepking.com/papers/Wiepking_Bekkers_VSR_2012 .pdf (accessed: 1.03.2020).

Zagefka, H., Trevor, J. (2015), The Psychology of Charitable Donations to Disaster Victims and Beyond, "Social Issues and Policy Review", 9, pp. 155-192, https://dx.doi .org/10.1111/sipr.12013

Zasimova, L., Kolosnitsyna, M. (2018), Charitable giving and the future of NGOs in Russia: what can we learn from individual data?, "Post-Soviet Affairs", 34 (6), pp. 412 429, https://dx.doi.org/10.1080/1060586X.2018.1508861

\section{Czy zaufanie społeczne wpływa na udzielanie wsparcia finansowego organizacjom pozarządowym?}

Celem artykułu jest ustalenie związku między poziomem dochodów organizacji pozarządowych a zaufaniem społecznym do nich. Badanie wykaże, czy zaufanie społeczne mierzone przez Charities Aid Foundation ma wpływ na dochody organizacji pozarządowych z działalności charytatywnej. Analizowane są dochody organizacji pozarządowych w Polsce, Chorwacji oraz Wielkiej Brytanii oraz zmiany w poziomie zaufania społecznego w tych krajach i w dochodach organizacji pozarządowych w latach 2013-2017. Dla realizacji celu badawczego zostały zastosowane takie metody badawcze jak analiza literatury i analiza regresji panelowej. Wyniki analizy regresji panelowej wskazują, że wysokość darowizn zależy nie tylko od poziomu zaufania publicznego, ale także od wielu czynników zewnętrznych. Stwierdzamy, że poziom dochodów organizacji pozarządowych jest różny w zależności od kraju, ze względu na różne poziomy rozwoju gospodarczego tych krajów i ich zamożności. Wyniki pokazują też, że poza obszarem demograficznym, na wysokość przychodów i wysokość darowizn dla organizacji pozarządowych wpływają także cel filantropijny, liczba lat, jakie upłynęły od założenia organizacji (wiek organizacji) oraz model finansowania. Ograniczenia badawcze wynikają z wyboru kilku krajów do analizy. Oryginalność i wartość niniejszego opracowania polega na tym, że problem niskiego zaufania społecznego do organizacji pozarządowych analizowany jest $w$ artykule poprzez powiązanie go $z$ dochodami tych organizacji.

Słowa kluczowe: organizacje pozarządowe, zaufanie społeczne, przychody, darowizny 


\section{Appendix 1}

Table 4. Issue of Accounting and other legal acts regulating the activity of NGOs in Poland, Croatia and the United Kingdom, 2009-2017

\begin{tabular}{|c|c|c|c|}
\hline Year & Croatia & Poland & United Kingdom \\
\hline 2009 & $\begin{array}{l}\text { Monitoring financial data } \\
\text { of non-profit organizations } \\
\text { as a sector } \\
\text { General data on subjects } \\
\text { and data relevant for the } \\
\text { database of financial re- } \\
\text { ports from the Registry } \\
\text { of non-profit organizations } \\
\text { become available to the pub- } \\
\text { lic according to the ordinates } \\
\text { of the Law on the right to ac- } \\
\text { cess information (the excep- } \\
\text { tion being so-called small } \\
\text { non-profit organizations). }\end{array}$ & & \\
\hline \multicolumn{4}{|l|}{2010} \\
\hline 2011 & & $\begin{array}{l}\text { Obligation to publish a fi- } \\
\text { nancial and activity report } \\
\text { on the government website. }\end{array}$ & $\begin{array}{l}\text { The definition of a charity } \\
\text { was also incorporated into } \\
\text { tax law so that charities can } \\
\text { obtain tax relief. } \\
\text { The Charity Commission has } \\
\text { a new public benefit objec- } \\
\text { tive, "to promote awareness } \\
\text { and understanding of the op- } \\
\text { eration of the public benefit } \\
\text { requirement. }\end{array}$ \\
\hline \multicolumn{4}{|l|}{2012} \\
\hline \multicolumn{4}{|l|}{2013} \\
\hline 2014 & $\begin{array}{l}\text { The new Law on Associa- } \\
\text { tions. }\end{array}$ & $\begin{array}{l}\text { Like other entities, NGOs are } \\
\text { obliged to fulfil regulations } \\
\text { of the Accounting Act. How- } \\
\text { ever, they can prepare sim- } \\
\text { plified financial statements } \\
\text { if they do not run a business. }\end{array}$ & $\begin{array}{l}\text { The Charities (Exception } \\
\text { from Registration) Regula- } \\
\text { tion - charities that do not } \\
\text { reach a gross annual income } \\
\text { of } £ 100,000 \text { are not required } \\
\text { to register with the Charity } \\
\text { Commission. }\end{array}$ \\
\hline
\end{tabular}




\begin{tabular}{|c|c|c|c|}
\hline Year & Croatia & Poland & United Kingdom \\
\hline 2015 & $\begin{array}{l}\text { Coming into force of the Law } \\
\text { on Financial Operations and } \\
\text { Accountancy of Non-Profit } \\
\text { Organisations. } \\
\text { Obligation to self-assess fi- } \\
\text { nancial management and } \\
\text { to enforce control. } \\
\text { Obligation to make plans for } \\
\text { large non-profit organiza- } \\
\text { tions. } \\
\text { Obligation to create financial } \\
\text { reports. } \\
\text { All financial reports made } \\
\text { public through the Registry } \\
\text { of non-profit organizations. }\end{array}$ & $\begin{array}{l}\text { Law on public benefit activ- } \\
\text { ity and volunteering - full } \\
\text { and simplified activity re- } \\
\text { ports. Some NGOs do not } \\
\text { have to prepare financial } \\
\text { statements. }\end{array}$ & $\begin{array}{l}\text { Income criterion for audit } \\
\text { and the threshold for pre- } \\
\text { paring consolidated (group) } \\
\text { accounts. }\end{array}$ \\
\hline 2016 & & & $\begin{array}{l}\text { Charities (Protection and } \\
\text { Social Investment) Act } \\
2016 \text { - higher control over } \\
\text { charities*. } \\
\text { Introduction of SORP FRS } \\
\text { (based on IFRS) for first re- } \\
\text { ports in 2019. } \\
\end{array}$ \\
\hline 2017 & & $\begin{array}{l}\text { Creation of the National In- } \\
\text { stitute of Freedom - Cen- } \\
\text { tre of Civil Society Develop- } \\
\text { ment, which is responsible } \\
\text { for the distribution of grants } \\
\text { and information on NGOs. }\end{array}$ & \\
\hline
\end{tabular}

* https://www.ncvo.org.uk/policy-and-research/charity-law-and-regulation (accessed: 27.10.2020). Source: own elaboration. 